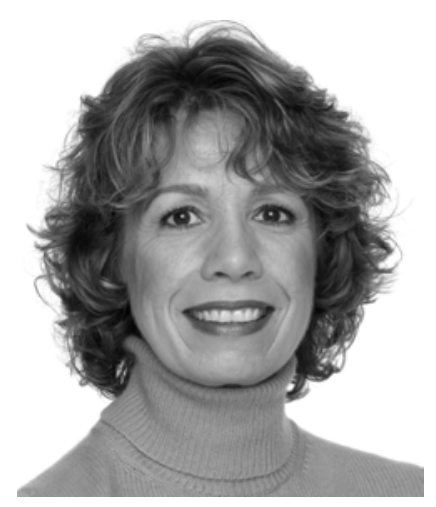

\title{
Bearers of Light
}

Joan Bauer was kind enough to let us print her speech, given at the ALAN Workshop, which was entitled "Bearers of Light: The Caring Community of Young Adult Literature," in Pittsburgh, Pennsylvania, November 21, 2005.

I 've been asked to talk about light this morning. And light isn't one of those easily contained subjects because it tends to mean different things to different people. But when I think about light, I think about candles. And when I think about candles, I think about my daughter's baptism.

It was twenty three years ago now. My husband, Evan, and I had been told what to expect during the ceremony. The minister sprinkled the water on Jean's head; she didn't cry-I did. He gave her to my husband, and then the pastor did something we hadn't expected. He handed me a big candle, lit it, and said, "Never let the light of God go out in your child's life."

I held the flaming candle, quite stirred, and vowed, "I won't. I swear." Evan gave me a look. I muttered "amen." We went back to our seats in the second row of the church. I was still holding the burning candle as Jean gurgled happily.

I sat there with the candle. It was early in the service.

We sang a few hymns-not easy when you're holding a burning candle. Bible verses were read, and by now the hot wax was beginning to form. I tipped the candle over; the wax dripped down my pants leg. Evan whispered that we could take Jean out, but the minister was climbing into the pulpit for his sermon, and I didn't want to be rude-this is one of the real downsides of sitting in the second row. By now hot wax was dripping down my hand, and I didn't know what to do because I'd just taken a vow in public that
I wouldn't let the light of God go out in my kid's life, and to blow the candle out seemed, you know, hostile. Evan whispered that Jean would start crying any minute and then we could take her out, but she didn't cry.

I'm not proud of this-I took her bottle. But she didn't cry; she just gurgled-transfixed by the flame.

I took her toy. That didn't work either. By now hot wax was scarring my hand, and I thought, no offense, God, and blew out the flame.

Then she started wailing.

"It's just a symbol," I stammered.

Being a bearer of light can be a lot of pressure.

Let's face it, light isn't always appreciated. It's got heat, it burns, it shows things we'd rather not see like the dust on your coffee table and the stain on your carpet. Light can be tough on the fashion conscious. Ever go out of the house and realize what you're wearing clashes because you didn't see it in good light? Or the black shoes you thought you put on were actually brown, and you spend more time than you'd like that day hiding in the shadows.

Light comes to us in so many forms-lamps, flashlights, laser beams, lighthouses. Morning light is hopeful, a lamp turned on is illuminating, the heat of a fire, depending on the situation and your mood, can be warming or threatening. The one thing all light has in common is that it changes every place it streams into. Think about what Rembrandt's work would be like, or Vermeer's paintings, without that light. Well drawn, certainly, but lacking something so deep. I 
wonder what they carried in their hearts to be able to paint like that. They bore the light, carrying it from their hearts to the canvas.

And there is the heart-stirring, dramatic light that Olympic runners carry. I used to be a runner (not like that!), and I always thought there was no greater moment than when the last runner lifts the torch, runs across the bridge/the platform, etc. and up all the stairs as the music swells and the Olympic flame is ignited.

I'm sorry, you couldn't get that same effect with smoke machines, laser shows, or balloons-it's got to be on fire.

But it is dangerous, this light to which we're drawn. My family and I lived in southern California years ago during the season of big fires in the hills. We were driving up there one day and the sight of the fire was both frightening and strangely beautiful. We almost felt drawn to it-we wanted to get closer but knew that it was dangerous.

What is it about light that draws us and holds us back?

I think the great powers in life, actually, draw us and we pull away. Love can be the greatest thing we desire, and yet when it comes it can seem like too much; we pull back afraid. We can say we seek truth with all our hearts, but sometimes when it appears we're repelled by it. We are complex creatures who live in the light and hide in the shadows that it offers. And to walk this world right now trying to find the light, much less bear it, is a daunting task.

As I was forming these remarks, I had a period of real illumination and I felt I was beginning to understand what I wanted to say. That made me hungry. I went to the grocery store, partially illuminated. And as I stood there at the check out line, I was besieged by the Dark Side. The magazine racks, that is, and the headlines:

Brad and Angelina - The Real Truth

Brad and Angelina - Like You've Never Seen Them Before

Why Men Won't Tell You What They Really Want

Why Women Won't Tell You Either

And my personal favorite of 2005 . . .

Madonna's Tips on Parenting
All of this sandwiched between the covers of Katrina victims trying to start again, and all the tragedies and horrors of our time.

I stood there numb and felt all the light within me diminish. I bought my fudge-covered Oreos and slumped home. How easily light is diminished.

We can learn about light from ancient man and woman who first figured out about making fire. Never take fire for granted. It needs to be fed to keep going.

But the truth is, being a bearer of light has a downside, a painful side: candles burn out, people in lighthouses are lonely. A dear friend of mine works in stained glass. How I love that art form, but the cost to the artist is real-cut hands from working with sharp glass and sharp tools.

We don't need light in the day nearly as much as we need it at night. Once a year in New York City, two beams of laser light stand in the night sky, a powerful tribute to the World Trade Center-it's such a quiet, powerful memorial. What will the memorials be for Katrina, Iraq, the Tsunami, Bali? It's too soon to know, I suppose. Disasters keep coming at us so fast. We need the light. And yet, it is so hard to keep close. It is so very hard to bear.

There was a terrorist threat in New York City where I live over Presidents' Day. The subways, we were told, had been targeted. You couldn't get a car or a taxi that day. I took the subway and I admit it, the fear and the headlines got to me. I was scared. It seemed like every rider in my subway car had a newspaper and every headline blared SUBWAY TERROR THREAT-NYC ON HIGH ALERT.

I tried to stand like I was on high alert.

Come on, make my day.

But I was having some lower back pain and the suitcase I dragged on the subway was getting in people's way. The car was stuffy and the fear of what could happen to all of us just hung in the stale air. I looked up at the ad from Dr. Sherman Kazinsky, a plastic surgeon, who said that he had helped many women my age turn into really hot numbers with liposuction. All I had to do to begin this new sultry existence was call his 800 number.

I sucked in my stomach-on high alert. I wondered if my subway car was going to be blown up, wondered if the last thing I would read on this earth was an ad for liposuction. 
I looked at the faces of my fellow travelerseveryone had to be a little afraid, but there we were on the subway, sticking out our tongues in terrorism's face. Woody Allen said that $90 \%$ of success is just showing up. And we'd done that, damn the threats, all bearing in some small way, the light of resolve.

I try to find moments of light when I create my characters. I want them, I need them, to carry a light inside-it's the only way they can make it through the darkness. I think of it as their inner lighthouse. And I have to know where it came from before I can bring it forth.

In Ellie Morgan of Squashed, it's her unbowed stance on being who she is, hopelessly P.O. (pumpkin obsessive). For A.J. McCreary of Thwonk, it's her artist's eye that appreciates weird light. Harry Bender's light came from spending so much time in the dark regions of alcoholism and finding the way out. Hope Yancey's light comes, in part, from her determination to live and rise to the power of her name. It's not easy:

Harrison Beckworth-McCoy, my best male friend at school had given me a good-bye present, and I was opening it now as Addie pushed the Buick through Ohio. Inside the box was a small glass prism that caught the sun. A hand-painted note from Harrison read, "New places always help us look at life differently. I will miss you, but won't lose you."

Enter memories, sweet and sour.

Harrison and me baking enormous moch a chip cookies for the high school bake sale and having them stolen on the Lexington Avenue subway.

Harrison's African fighting fish, Luther, who ate Chef Boyardee Ravioli without chewing.

Harrison reading my mother's photocopied annual Christmas letter that she sent to family and friends - "Dear Friends ..." (she'd cross out friends and write in "Addie and my little Tulip.") Harrison commenting that motherhood should be like driving a car-you should have to pass a test before you get to do it legally.

I held the prism up to the light. The sun hit it and showered colors through the windshield.

"Now isn't that something?" Addie said, smiling at the sight.

"Yeah," I looked out the window, trying not to cry.

Mrs. Gladstone of Rules of the Road and Best Foot Forward has a special kind of light and if you mentioned it to her, she would probably get huffy. But the light she bears is doing the right and hard thing. Mrs.
Gladstone's light is costly because it comes at the cost of her relationship with her son and the role she plays in her company. She is a lonely bearer of light, but because of that she's not swayed by darkness, not drawn to it. She doesn't compromise. Her light changes lives. There are just some people put on this earth that were created to fight the hard battles.

Tree Benton in Stand Tall is curious about the light. He packs big questions into everyday moments:

Getting ready for bed, watching the clock tick off the seconds, minutes. On Saturday Tree had taken the clock apart to see how it was made, and when he put it back together, there were two parts left on the table. He didn't trust the clock much after that.

He got into his queen-size bed, lay at an angle, covered himself with two blankets. Angle sleeping gave him more room.

He had heard that people grow when they sleep, so last year he'd tried to stay awake to stop his bones from expanding. He was so tired, he kept tripping over Bradley, who up to that time had felt safe sleeping in the hall.

A cold draft blew into the room. He hadn't minded a drafty room as much when his parents were still married, but his room seemed colder these days.

He tried to sleep. Couldn't.

Got out the cool laser pen his father had gotten him from the sporting goods show at the convention center.

Took out the insides. Put each part on the desk. Studied the laser section-it was so small to make such a big light.

There was beauty in seeing how things worked, machines in particular.

Grandpa taught him that.

He put the pen back together piece by piece, saw the clean lines of each ink cartridge, the small tunnel for the laser beam that had to be fixed on the little battery just so. The batteries had to be put in the right way or the flashlight wouldn't work. There was no other road to take in the battery world-the negative and positive ends had to be touching.

He turned out the light and shone the laser on the wall, making circles and slashes like a space warrior.

He wished life could be simple like a laser pen-with clean lines and a clear purpose.

Jenna Boller is no stranger to the light. And she sees it, too, in everyday places. Here's one of those moments in Best Foot Forward as Jenna "lovingly" locks the door of her new car: 
My new car was glistening red and cool in the early morning light. People talk about light dancing off a lake in summer or sunshine pouring through a kitchen window, but there's a true beauty to light beaming off the hood of a recently washed red car that is absolutely yours.

But in every story I write there's always a black hole of sorts that the main character falls into for awhile and struggles to find the light.

Jenna, surrounded by the pain of her dad's alcoholism.

Hope Yancey in Hope Was Here, carried off against her will to the land of lactose.

Ivy Breedlove in Backwater, climbing a tall mountain in the middle of winter to find her hermit aunt.

A.J. McCreary in Thwonk, plunged into the darkness of unrequited love.

Mickey Vernon in Sticks, beaten again and again by the dirty rotten bully.

Scientists tell us that black holes in space are places devoid of light. I know a bit about places like that.

I struggled with so much as a teenager. Like Jenna, my dad was an alcoholic. The pain of that followed me for years. Whenever I think of that time, I remember Garrison Keillor's story about a woman named Margaret. "Margaret,” Keillor explained, “did not believe in God, but there was a great deal of evidence to show that God believed in Margaret."

I spent several years as an atheist before I moved on to agnosticism. And then, when I was twenty-four years old, I entered one of life's black holes-a place devoid of light.

My father committed suicide.

There was no hope, no comfort, only the darkness of regret and unrelenting sorrow.

I don't remember getting on the airplane. Don't remember getting to the funeral home, but I remember walking in the door and seeing the casket and all the years of our complicated relationship just hit me.

What a colossal waste of a gifted life.

I was numb, of course, I couldn't function. And then something happened. It was dramatic, too, because clear and plain was the only way I was going to pay attention.

I felt a hand on my shoulder. I turned around. No one was there.

It was God's hand.
And in the days and weeks to follow, that hand never left me. It steadied me, it gave me comfort, I stopped feeling alone, it opened the windows of my heart and, little by little, the light came through again. I will never forget when God made Himself so real to me. It has changed everything in my life, that touch. It influences everything I do. All my writing comes from that time of contact. I don't have the words to tell you how that moment of deepest loss opened the door to deepest gain.

There are human hands, of course, that lift us:

A teacher takes extra time so a struggling student can learn to read.

A librarian takes an illuminated story and shares it again and again.

A friend comes to sit with us in the dark and brings light.

A child comes up and hugs us when we need it the most.

It's a journey to find and keep the light. Part of it requires maintenance because lights go out. How well I know this.

I live in an 1875 brownstone in Brooklyn with wonderfully tall ceilings and recessed lighting. It's just so charming until you have to change the light bulbs. My husband and I actually sit in semi darkness as bulb after bulb burns out until we finally can't stand it anymore, for we know the painful road we must travel to find the light.

It begins with the ladder from hell.

It weighs 65 pounds and has to be endlessly unfolded, like aluminum origami.

Evan is up on the 8 foot rung, trying to unscrew the recessed bulbs that the realtor assured us would “just pop out”- -he's turning like a contortionist and groaning because he has a bad back. My job is to keep the ladder steady, hand the new bulbs up and shout at him to be careful. It's not the most magic time in our marriage.

Hours later when all the bulbs are in and all the lights are on, we flop on the couch and say, "Well, that was almost worth it!"

Maybe we'd feel differently if someone applauded when we were through.

More and more I'm thinking about Olympic torch carriers-there they are in prime condition with good posture. They don't falter. They are assured of their mission. They don't get shin splints like I used to get 
as a runner. They know they're going to be appreciated when they run up the steps, not breathing hard, to light the great flame.

Teachers and librarians are no strangers to lugging things up stairs, but you rarely get applause when you get to the top. You can stand there with your torch all alone with no place to ignite it for the glory of literature.

There's no eternal flame to honor books, except that is, in the hearts of true readers.

I'm a reader and my candle is lit from within.

And as for Dr. Sherman Kazinsky and his liposuction-I won't get that ever!

I've earned my cellulite-it's from the layers and layers of all the books I've read, the stories that have made me weep and laugh, the characters that have challenged me and changed me and pressed my skin to new horizons.

Listen up, Dr. Kazinsky. Humor is emotional liposuction-it sucks out the stuff that's causing your soul to ripple and injects you with joy!

In this super-sized, turbo-charged age, a book can seem like a small thing. A light on a key chain does, too, until you press it and the light comes forth. I was intrigued to learn that the word metaphor comes from the Greek, which means to bear, to carry over. Maybe that's why we have sore backs and shoulders. As Don Gallo so well said, we're struggling against so much that would pull education down, but God bless you, you're carrying it, bearing it, and the power of that is incalculable to measure.

To bear a thing, to lift it up, to carry it all the way . .

Pregnancy, whether in actuality or in metaphor, always makes its presence known.
So if you're feeling a little nauseous in the mornings, if you've got lower back pain, if you're tired and cranky; if your stomach is getting a tad too big for your jeans, and your ankles are swollen. If you're weepier than normal, not sleeping too well at night, feeling some odd stirrings in your belly, a kick now and then ...

You just might have a light within you that is growing. It won't be all roses carrying it through, but to bear it is an honor.

So raise the blinds high, Open the windows,

Fling wide the doors,

And let there be light!

Copyrights, both written and electronic, belong solely to Joan Bauer; this article may not be reprinted or reproduced without her express, written permission.

Joan Bauer has a gorgeous website, maintained by Evan Bauer, her husband, at www.joanbauer.com. Joan has been well-described as an author who "explores difficult issues with humor and hope." Among the awards she has won are: the Newbery Honor Medal, the LA Times Book Prize, the Christopher Award, the Golden Kite Award of the Society of Children's Book Writers and Illustrators, ALA Notable Book, ALA Best Book, ALA Quick Pick, American Bookseller Pick of the List, School Library Journal Best Book, Smithsonian Notable Children's Book, and VOYA's Perfect 10. Joan's appearances are cherished events for members of ALAN who have been fortunate enough to see and meet her in person. She and her husband, Evan, live in Brooklyn, New York, where their daughter, now in graduate school, is a regular visitor. 